\title{
Study on antioxidant and physiological activities of extract from Ligularia fischeri by extraction methods
}

\author{
Yeon-jeong Woo, Seung-Ryeul Shin, Ju-Yeon Hong * \\ Faculty of Herbal Food Cuisine and Nutrition, Daegu Haany University, Gyeongsan 38610, Korea
}

\section{추출방법을 달리한 곰취(Ligularia fischeri) 추출물의 항산화 및 생리활성에 관한 연구}

\author{
우연정 · 신승렬 · 홍주연 * \\ 대구한의대학교 한방식품조리영양학부
}

\begin{abstract}
The purpose of this study was to determine antioxidant and physiological activities of water and $70 \%$ ethanol extracts from Ligularia fischeri by extraction methods. The yield of water and ethanol extracts from Ligularia fischeri was $15.23 \%$ and $17.45 \%$, respectively. The polyphenol and flavonoid contents of ethanol extracts of Ligularia fischeri (LEE) were $17.17 \pm 4.38 \mathrm{mg} / \mathrm{g}, 35.06 \pm 6.69 \mathrm{mg} / \mathrm{g}$, respectively. The electron donating ability and SOD like activity, and ABTS radical ability of all Ligularia fischeri extracts were increased in a dose dependent manner, and those

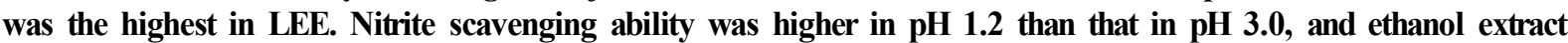
showed higher ability in pH 1.2 and 3.0. The xanthine oxidase and inhibition effect of all Ligularia fischeri extracts on tyrosinase were dose-dependently increased, and those was the highest in ethanol extracts of Ligularia fischeri. Reducing power was 1.2 at extract concentration $1,000 \mu \mathrm{g} / \mathrm{mL}$ in water and ethanol extracts of Ligularia fischeri and the highest in water extract of Ligularia fischeri at concentration of $62.5-500 \mu \mathrm{g} / \mathrm{mL}$. These results may contribute to development of processed food and health functional food with Ligularia fischeri.
\end{abstract}

Key words : Ligueria fischeri, antioxidant, physiological activities, functionality

\section{서 론}

최근 세계적으로 경제발전에 따른 전체적인 식품소비 구조의 변화, 특히 식품의 웰빙화, 건강 기능성 식품의 소비 증가 등의 식생활 환경의 변화는 건강한 삶에 대한 옥구를 증가시키고 있으며, 이와 함께 고부가가치 식품 및 건강 기능성 식품산업에 대한 수요와 시장규모를 점차 확대시키 고 있다(1). 건강한 삶에 대한 욕구는 건강, 체지방 감소, 항산화, 면역 증강 등 구체화됨에 따라 개별 욕구와 관련된

*Corresponding author. E-mail : pinkpunk@dhu.ac.kr Phone : 82-53-819-1426, Fax : 82-53-819-1494

Received 11 October 2017; Revised 12 December 2017; Accepted 18 December 2017.

Copyright (c) The Korean Society of Food Preservation. All rights reserved.
기능성 원료를 함유한 다양한 건강 기능 식품이 연구·개발 되고 있다(2). 아울러 평균수명이 길어지면서 건강한 노후 에 대한 관심이 고조되고 천연물 중 부작용이 없고 유독하 지 않은 소재를 이용한 건강 유지 및 증진에 대한 요구가 증가하고 있다(3).

식물성 식품에 널리 존재하는 페놀 화합물 및 비타민 등의 천연 항산화제가 산화손상에 대한 화학적 예방 촉매기 능(4)이 알려짐에 따라 저공해 채소류, 약리작용이 우수한 채소 및 산채류에 대한 관심이 커지고 있다 $(5,6)$. 산채류는 비타민류와 무기질을 많이 함유하고 있으며(7), 약리효능 으로는 항종양 및 암세포에 대한 세포독성(8), 간기능 개선 (9), 항비만(10), 항균효과(11) 등이 보고되고 있다. 특히 산채류는 약리작용과 건강 기능성이 탁월하여 인간의 삶과 질을 향상시켰으며, 이는 산야의 자생 또는 재배 산채류가 메디케어 관련 건강기능식품, 뷰티 화장품, 의약품 등의 
소재로 사용이 가능할 것으로 평가하였다(12).

곰취(Ligularia fischeri)는 국화과(菊花科)에 속하는 다년 생 초본식물로 웅소(雄蔬)라고도하며 곰취라는 이름은 곰 이 좋아하는 나물에서 온 것이다(13). 곰취는 유럽과 아시아 에 10 여종이 분포하는데 그중에서 9 종이 우리나라의 품종 이며, 어린잎을 식용으로 이용하는데 주로 나물이나 쌈, 장아찌로 섭취한다. 약리학적인 측면에서 살펴보면 곰취는 예로부터 기침, 가래, 다리 아픔, 요통, 두통, 백일해, 천식에 효험을 나타내며(14), 혈액순환을 활발하게 한다고 알려져 있다. 민간에서는 황달, 고혈압, 간장병에 사용했으며, 다치 고 헌데에 균이 들어간 전염성피부(단독)병과 고름집에 잎 을 찧어 붙이곤 했다(15). 영양적인 측면에서 곰취는 각종 비타민과 무기질을 고루 함유하고 있다. 그 중 비타민A $780 \mathrm{RE} / 100 \mathrm{~g}, \beta$-carotene $4,681 \mu \mathrm{g} / 100 \mathrm{~g}$, 칼슘 $241 \mathrm{mg} / 100$ $\mathrm{g}$, 칼륨 $778 \mathrm{mg} / 100 \mathrm{~g}$, 섬유소 $1.7 \mathrm{~g} / 100 \mathrm{~g}$ 을 함유하며, 철분 은 $30.926 \mathrm{mg} / 100 \mathrm{~g}$ 으로 매우 높게 함유하고 있다(16). 곰취 의 아미노산 총량은 $3,562 \mathrm{mg} / 100 \mathrm{~g}$ 으로 이 중 풍미와 관련 된 아미노산인 glutamic acid, aspartic acid, glycine과 alanine 이 높은 비율을 차지하고, 8 개의 필수아미노산 중 threonine, valine, isoleucine, leucine, phenylalanine과 lysine은 전체 아 미노산 함량 중 상당 부분을 구성하고 있다(17).

곰취는 특유의 향과 맛이 뛰어나 조선시대의 고서에서도 자주 등장할 만큼 오래전부터 즐겨오던 산나물로서 영양적 인 측면에서 우수하며, 산채로서의 뿐만 아니라 한약재로 도 오랫동안 사용되어져 왔다. 곰취의 기능성 및 생리 활성 의 연구는 곰취의 기능성을 학문적으로 규명하고, 기능성 이 우수한 식재료에 대한 정보를 제공할 뿐만 아니라 곰취 의 소비 증대를 촉진할 수 있을 것으로 기대한다. 따라서 본 연구는 자생하고 있는 곰취 열수 및 $70 \%$ 에탄올 추출물 을 제조하여 추출물의 항산화효과 및 생리활성에 대한 연구 를 수행하였다.

\section{재료 및 방법}

\section{실험 재료}

본 연구의 주재료인 곰취(Ligularia fischeri)는 경북 영양 군 일원에서 재배된 것을 구입하였으며, 모든 시료는 정상 적인 녹색 빛을 띠는 것을 선별하여 흐르는 물에 3회 깨끗하 게 세척한 후 물기를 제거하고 일정량으로 분취하여 초저온 냉동기(MDF-U52V, Sanyo, Osaka, Japan)에 보관하면서 시 료로 사용하였다.

\section{추출물의 제조}

곰취 열수 추출물은 각 시료에 10 배에 해당하는 3 차 증류 수를 각각 가한 후 $85^{\circ} \mathrm{C}$ 에서 3 시간 동안 환류 추출하였고 이 과정을 3회 반복 추출하여 모아진 추출액을 여과지
(Whatman No.2)로 여과하여 제조하였다. 곰취 에탄올 추출 물은 각 시료에 10 배의 $70 \%$ 에탄올을 가한 후 $50^{\circ} \mathrm{C}$ 에서 3 시간 동안 환류 추출하였다. 이 과정을 3 회 반복 추출하여 모아진 추출액을 여과지(Whatman No.2)로 여과하여 제조 하였다. 추출액은 회전식 감압증발 농축기(R-210, BUCHI, Kyudo, Japan)를 사용하여 감압농축하였고, 동결건조기 (FD8512, Ilshin, Seoul, Korea)로 $-90^{\circ} \mathrm{C}$ 에서 동결건조한 후 플라스틱용기에 담아서 초저온냉동기에 보관하면서 시료 로 사용하였다. 그리고 시료의 추출 수율은 추출 전 시료 중량에 대한 추출물의 동결건조 후의 중량 백분율로 나타내 었다.

\section{폴리페놀 측정}

폴리페놀 화합물의 정량은 Folin-Denis 법(18)으로 측정 하였다. 즉, 곰취 열수 및 에탄올 추출물을 $10 \mathrm{mg} / \mathrm{mL}$ 농도로 증류수에 녹인 다음 $0.2 \mathrm{~mL}$ 를 시험관에 취하고 증류수를 가하여 $2 \mathrm{~mL}$ 로 만든 후 여기에 $0.2 \mathrm{~mL}$ Folin-Ciocalteu's phenol reagent를 첨가하여 잘 혼합한 후 3 분간 실온에 방치 하였다. 정확히 3 분 후 $\mathrm{Na}_{2} \mathrm{CO}_{3}$ 포화용액 $0.4 \mathrm{~mL}$ 를 가하여 혼합하고 증류수를 첨가하여 $4 \mathrm{~mL}$ 로 만든 후 실온에서 1시간 방치하여 흡수분광광도계(UV-2001, Hitachi, Tokyo, Japan)를 이용하여 $725 \mathrm{~nm}$ 에서 흡광도를 측정하였다. 이때 총 폴리페놀 화합물은 tannic acid(Sigma-Aldrich Co., St. Louis, MO, USA)를 이용하여 작성한 표준곡선으로부터 곰취 열수 및 에탄올 추출물에 함유된 폴리페놀 화합물 함량을 산출하였다.

\section{플라보노이드 측정}

플라보노이드 함량은 Moreno 등이 행한 방법(19)에 따라 곰취 열수 및 에탄올 추출물을 $10 \mathrm{mg} / \mathrm{mL}$ 농도로 증류수에 녹인 시료 용액 $0.1 \mathrm{~mL}$ 를 취하여 $10 \%$ aluminum nitrate와 $1 \mathrm{M}$ potassium acetate를 함유하는 $80 \%$ ethanol $4.3 \mathrm{~mL}$ 에 혼합하여 실온에서 40 분간 정치 한 후 흡수분광광도계를 이용하여 $415 \mathrm{~nm}$ 에서 흡광도를 측정하였다. 총 플라보노이 드 정량은 quercetin(Sigma-Aldrich Co.)을 이용하여 작성한 표준곡선으로부터 산출하였다.

\section{전자공여능 측정}

전자공여능은 Blois 등의 방법(20)에 준하여 각 시료의 1,1-diphenyl-2-picryl hydrazyl(DPPH)에 대한 전자공여 효 과로써 시료의 환원력을 측정하였다. 즉 각 추출물을 농도 별로 제조한 시료 $2 \mathrm{~mL}$ 에 $0.2 \mathrm{mM} \mathrm{DPPH}$ 용액 $1 \mathrm{~mL}$ 를 가하 고, 10 초간 vortex mixing 후 $37^{\circ} \mathrm{C}$ 에서 30 분간 반응시킨 다음 이 반응액을 분광광도계를 사용해서 $517 \mathrm{~nm}$ 에서 흡 광도를 측정하였다.

대조구는 천연 항산화제인 L-ascorbic acid를 사용하였 고, 아래와 같이 시료첨가구와 무첨가구의 흡광도의 차이 
를 백분율(\%)로 표시하여 전자공여능으로 나타내었다.

$$
\begin{aligned}
& \text { Electron donating ability }(\%)=\left(1-\frac{\mathrm{S}-\mathrm{B}}{\mathrm{C}}\right) \times 100 \\
& \text { S : sample 첨가구의 흡광도 } \\
& \text { B : blank의 흡광도 } \\
& \text { C : control(시료 무첨가구)의 흡광도 }
\end{aligned}
$$

\section{$\mathrm{SOD}$ 유사활성 측정}

SOD 유사활성 측정은 Marklund 등의 방법(21)에 따라 각 시료 $0.2 \mathrm{~mL}$ 에 $\mathrm{pH} 8.5$ 로 보정한 tris- $\mathrm{HCl}$ buffer $(50 \mathrm{mM}$ tris[hydroxymethyl] amino-methane $+10 \mathrm{mM}$ EDTA) $3 \mathrm{~mL}$ 와 $7.2 \mathrm{mM}$ pyrogallol $0.2 \mathrm{~mL}$ 를 가하였다. 그런 다음 $25^{\circ} \mathrm{C}$ 에서 10 분간 반응시킨 후 $1 \mathrm{~N} \mathrm{HCl} 0.1 \mathrm{~mL}$ 로 반응을 정지시키고 $420 \mathrm{~nm}$ 에서 흡광도를 측정하였다. SOD 유사활성은 시료 첨가구와 무첨가구 사이의 흡광도 감소율로 산출하였다. SOD 유사활성은 시료 첨가구와 시료 무첨가구 사이의 흡 광도의 감소율로 아래와 같이 환산하였으며, 대조구로는 L-ascorbic acid를 사용하였다.

$$
\text { SOD like activity }(\%)=\left(1-\frac{\mathrm{S}-\mathrm{B}}{\mathrm{C}}\right) \times 100
$$

$$
\begin{aligned}
& \text { S : sample의 흡광도 } \\
& \mathrm{B}: \text { blank의 흡광도 } \\
& \mathrm{C}: \text { control(시료 무첨가구)의 흡광도 }
\end{aligned}
$$

\section{ABTS(ABTS radical scavenging) 라디칼 소거활 성 측정}

$\mathrm{ABTS}$ 소거활성 측정은 $\operatorname{Re}$ 등(22)의 방법에 따라 7.4 $\mathrm{mM}$ 2,2-azinobis-(3-ethylbenzo-thiazoline-6-sulphonate) (ABTS) 와 $2.6 \mathrm{mM}$ potassium persulfate를 혼합하여 실온 - 암소에서 24시간 동안 방치하여 radical을 형성시킨 다음 실험 직전에 $\mathrm{ABTS}$ 용액을 $732 \mathrm{~nm}$ 에서 흡광도가 $0.70 \pm 0.03$ 이 되도록 phosphate buffer saline(PBS, pH 7.4)로 희석하여 사용하였 다. 희석된 용액 $950 \mu \mathrm{L}$ 에 추출물 $50 \mu \mathrm{L}$ 를 가하여 암소에서 10 분간 반응시킨 후 분광광도계를 사용해서 $732 \mathrm{~nm}$ 에서 흡광도를 측정하였다. ABTS 라디칼 소거능은 시료 첨가구 와 시료 무첨가구 사이의 흡광도의 감소율로 아래와 같이 환산하였으며, 대조구 L-ascorbic acid를 사용하였다.

ABTS radical scavenging ability $(\%)=\left(1-\frac{\mathrm{S}}{\mathrm{C}}\right) \times 100$

$$
\begin{aligned}
& \text { S : sample의 흡광도 } \\
& \text { C : control(시료 무첨가구)의 흡광도 }
\end{aligned}
$$

아질산염 소거능 측정

아질산염 소거능은 Kato 등의 방법(23)에 따라 다음과
같이 측정하였다. 즉 $1 \mathrm{mM}$ 의 $\mathrm{NaNO}_{2}$ 용액 $2 \mathrm{~mL}$ 에 각 농도의 시료 $1 \mathrm{~mL}$ 를 첨가하고, 여기에 $0.1 \mathrm{~N} \mathrm{HCl}(\mathrm{pH} 1.2)$ 과 0.1 $\mathrm{M}$ 구연산 완충용액을 사용하여 반응용액의 $\mathrm{pH}$ 를 1.2 로 조정한 후 반응용액의 부피를 $10 \mathrm{~mL}$ 로 하였다. 그리고 $37^{\circ} \mathrm{C}$ 에서 1 시간 동안 반응시켜 얻은 반응액을 $1 \mathrm{~mL}$ 씩 취하고 여기에 $2 \%$ acetic acid $5 \mathrm{~mL}$ 를 첨가한 다음 Griess reagent $0.4 \mathrm{~mL}$ 를 가하여 혼합시켰다. 그런 다음 실온에서 15 분간 방치시킨 후 분광광도계를 사용하여 $520 \mathrm{~nm}$ 에서 흡광도를 측정하여 잔존하는 아질산염의 백분율(\%)로 나타내었다.

$\mathrm{pH} 1.2,3.0$ 에서 추출물의 농도에 따른 아질산염 분해 작용은 $1 \mathrm{mM}$ 의 $\mathrm{NaNO}_{2}$ 용액 $1 \mathrm{~mL}$ 에 각 농도의 각 추출물을 첨가하고 여기에 $0.1 \mathrm{~N} \mathrm{HCl}$ 을 사용하여 반응용액의 $\mathrm{pH}$ 를 $1.2,3.0$ 으로 조정한 후 반응용액의 부피를 $10 \mathrm{~mL}$ 로 하여 측정하였다. 무첨가구 L-ascorbic acid를 추출물의 농도와 동일하게 조제하여 사용하였고, 공시험은 Griess reagent 대신 증류수 $0.4 \mathrm{~mL}$ 를 가하여 같은 방법으로 행하였다.

$$
\begin{aligned}
& \text { Nitrite scavenging ability }(\%)=\left(1-\frac{\mathrm{S}-\mathrm{B}}{\mathrm{C}}\right) \times 100 \\
& \text { S : sample의 흡광도 } \\
& \text { B : blank의 흡광도 } \\
& \text { C : control(시료 무첨가구)의 흡광도 }
\end{aligned}
$$

\section{Xanthine oxidase 저해효과 측정}

Xanthine oxidase 저해효과는 Stripe와 Corte의 방법(24) 에 따라 측정하였다. 즉, 각 시료용액 $0.1 \mathrm{~mL}$ 와 $0.1 \mathrm{M}$ potassium phosphate buffer(pH 7.5) $0.6 \mathrm{~mL}$ 에 xanthine(2 $\mathrm{mM}$ )을 녹인 기질액 $0.2 \mathrm{~mL}$ 를 첨가하고 xanthine oxidase $(0.2 \mathrm{unit} / \mathrm{mL}) 0.1 \mathrm{~mL}$ 를 가하여 $37^{\circ} \mathrm{C}$ 에서 5 분간 반응시킨 후 $1 \mathrm{~N} \mathrm{HCl} 1 \mathrm{~mL}$ 를 가하여 반응을 종결하였다. 그리고 반응액에 생성된 uric acid의 양을 분광광도계로 $292 \mathrm{~nm}$ 에 서 흡광도를 측정하였다. Xanthine oxidase 저해 효과는 시 료용액의 첨가군과 무첨가군의 흡광도 감소율로 나타내었 다. Xanthine oxidase 저해효과는 시료 첨가구와 시료 무첨 가구 사이의 흡광도의 감소율로 아래와 같이 환산하였으 며, 대조구로는 천연 항산화제인 L-ascorbic acid를 사용하 였다.

$$
\text { Xantine oxidase inhibition }(\%)=\left(1-\frac{\mathrm{S}-\mathrm{B}}{\mathrm{C}}\right) \times 100
$$

S : sample의 uric acid 생성량

B : blank의 흡광도

$\mathrm{C}: \operatorname{control}($ 시료 무첨가구)의 uric acid 생성량

Tyrosinase 저해활성 측정

Tyrosinase 저해활성 측정은 Yagi 등의 방법(25)에 따라 
행하였다. 반응구는 $0.175 \mathrm{M}$ sodium phosphate buffer(pH 6.8) $0.5 \mathrm{~mL}$ 혼합액에 mushroom tyrosinase (110 unit $/ \mathrm{mL})$ $0.2 \mathrm{~mL}$ 을 첨가하여 $25^{\circ} \mathrm{C}$ 에서 2 분간 반응시켜 분광광도계로 $475 \mathrm{~nm}$ 에서 측정하였다. Tyrosinase 저해효과는 시료 첨가 구와 시료 무첨가구 사이의 흡광도의 감소율로 아래와 같이 환산하였으며, 대조구로는 L-ascorbic acid를 사용하였다.

Tyrosinase inhibition $(\%)=\left(1-\frac{\mathrm{S}-\mathrm{B}}{\mathrm{C}}\right) \times 100$

S : sample의 흡광도

$\mathrm{B}$ : blank의 흡광도

C : control(시료 무첨가구)의 흡광도

\section{환원력 측정}

추출물의 환원력은 Wong과 Chye의 방법(26)을 일부 변 형하여 측정하였다. 각 시료용액 $0.5 \mathrm{~mL}$ 에 $0.2 \mathrm{M}$ phosphate buffer(pH 6.6) $1 \mathrm{~mL}$ 와 $1 \%$ potassium ferricyanide $1 \mathrm{~mL}$ 를 넣은 다음 잘 혼합하고 $50^{\circ} \mathrm{C}$ 에서 30 분간 반응시킨 후 실온 으로 냉각시켜 $10 \% \mathrm{TCA}$ 용액 $1 \mathrm{~mL}$ 를 넣은 다음 10 분간 방치하였다. 이 중 $0.5 \mathrm{~mL}$ 를 취해 증류수 $1 \mathrm{~mL}$ 와 $0.1 \%$ $\mathrm{FeCl}_{3} 0.5 \mathrm{~mL}$ 를 가한 후 분광광도계로 $700 \mathrm{~nm}$ 에서 흡광도 를 측정하였다. 환원력은 흡광도의 측정값으로 나타내었으 며, 대조구로는 butyl hydroxy toluene(BHT, Sigma Aldrich Co.)를 사용하였다.

\section{통계처리}

$\operatorname{Park}(27)$ 의 방법을 응용하여 모든 실험은 3 회 이상 반복

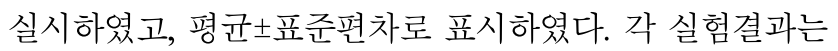
SPSS 통계프로그램(18.0, SPSS Inc, Chicago, IL, USA)을 이용하여 일원배치 분산분석 one-way ANOVA와 Duncan's multiple range test 실시하여 $\mathrm{p}<0.05$ 에서 유의성을 검증하 고, 분석하였다.

\section{결과 및 고찰}

추출물의 수율과 총 폴리페놀 및 플라보노이드 함량

곰취의 열수 및 $70 \%$ 에탄올 추출물의 수율 및 총 폴리페 놀 함량과 플라보노이드 함량을 측정한 결과는 Table 1 과 같다. 곰취 열수 및 에탄올 추출물의 수율 측정 결과 열수 추출물은 $15.23 \%$, 에탄올 추출물은 $17.45 \%$ 로서 에탄올 추 출물이 열수 추출물보다 수율이 높았다. 곰취의 열수 및 $70 \%$ 에탄올 추출물의 총 폴리페놀 함량은 곰취 열수 추출 물인 LWE에서 $8.26 \pm 3.26 \mathrm{mg} / \mathrm{g}$, 곰취 에탄올 추출물인 LEE 에서 $17.17 \pm 4.38 \mathrm{mg} / \mathrm{g}$ 으로 에탄올 추출물이 열수 추출물보 다 약 2 배 이상 폴리페놀의 함량이 높았다. 곰취의 열수 및 $70 \%$ 에탄올 추출물의 플라보노이드 함량은 곰취 열수
추출물 LWE에서 $15.41 \pm 8.24 \mathrm{mg} / \mathrm{g}$, 곰취 에탄올 추출물 $\mathrm{LEE}$ 에서 $35.06 \pm 6.69 \mathrm{mg} / \mathrm{g}$ 으로 열수 추출물보다 에탄올 추 출물에서 플라보노이드 함량이 높았다.

Hong 등(28)의 연구에서 생채 야생 참취를 물과 에탄올 로 추출 했을 때의 폴리페놀 함량은 각각 $20.43 \mathrm{mg} / \mathrm{g}, 16.30$ $\mathrm{mg} / \mathrm{g}$ 이었고, 플라보노이드 함량은 열수 및 에탄올 추출물 이 각각 $5.40 \mathrm{mg} / \mathrm{g}, 8.12 \mathrm{mg} / \mathrm{g}$ 으로서 본 연구 재료인 곰취의 폴리페놀 함량과 플라보노이드 함량이 참취보다 높았다. 또한 일부 약용식물 추출물에서 함유된 총 폴리페놀 함량을 측정한 Moon 등(29)이 애엽, 측백 등에 4.41-8.55 mg/g의 폴리페놀이 함유되었다는 결과와 비교하면 곰취 열수 및 에탄올 추출물에 함유된 폴리페놀 함량이 높았다.

Table 1. Yield and the contents of polyphenol and flavonoid in the extracts from Ligularia fischeri

\begin{tabular}{cccc}
\hline Sample $^{1)}$ & $\begin{array}{c}\text { Yield } \\
(\%)\end{array}$ & $\begin{array}{c}\text { Polyphenol } \\
(\mathrm{mg} / \mathrm{g})\end{array}$ & $\begin{array}{c}\text { Flavonoid } \\
(\mathrm{mg} / \mathrm{g})\end{array}$ \\
\hline LWE & $15.23 \pm 3.46$ & $8.26 \pm 3.26^{2 \mathrm{bb} 3)}$ & $15.41 \pm 8.24^{\mathrm{b}}$ \\
LEE & $17.45 \pm 2.32$ & $17.17 \pm 4.38^{\mathrm{a}}$ & $35.06 \pm 6.69^{\mathrm{a}}$ \\
\hline
\end{tabular}

${ }^{1)}$ LWE, Ligularia fischeri water extract; LEE, Ligularia fischeri ethanol extract. ${ }^{2)}$ All value are expressed as Mean \pm SD of triplicate determinations.

${ }^{3)}$ Different superscripts within the column are significantly different at $\mathrm{p}<0.05$ by Duncan's multiple range test.

\section{전자공여능}

곰취의 열수 및 $70 \%$ 에탄올 추출물의 항산화 활성 정도 를 측정하고자 농도별 1,1-diphenyl-2-picryl hydrazyl(DPPH) 에 대한 전자공여능을 측정한 결과는 Table 2 와 같으며 대조구로서는 천연 항산화제인 ascorbic acid를 사용하였다. 곰취의 열수 및 에탄올 추출물의 전자공여능은 농도가 증가 함에 따라 전자공여능은 증가하였다. 추출물 농도 1,000 $\mu \mathrm{g} / \mathrm{mL}$ 의 농도에서 곰취 열수 추출물인 LWE에서 $73.48 \%$, 곰취 에탄올 추출물인 LEE에서 $77.74 \%$ 로 에탄올 추출물에 서 다소 높은 전자공여능을 보였으며, 대조구인 ascorbic acid에서 $81.15 \%$ 의 전자공여능을 보여 곰취 에탄올 추출물 의 전자공여능과 큰 차이를 보이지 않았다. $62.5-125 \mathrm{\mu g} / \mathrm{mL}$ 의 농도에서는 대조구인 ascorbic acid가 $71.98-72.83 \%$ 의 전자공여능을 보였고, 곰취 열수 추출물 $\mathrm{LWE}$ 에서는 $68.77-69.87 \%$, 곰취 에탄올추출물인 $\mathrm{LEE}$ 에서는 73.13$74.29 \%$ 의 전자공여능을 보여 곰취 열수 추출물보다 에탄올 추출물에서 전자공여능은 높았고 대조구인 ascorbic acid보 다 곰취 에탄올 추출물이 다소 높은 전자공여능을 보였다.

전자공여능은 free radical에 전자를 공여하여 지 방질 산 화를 억제시키는 척도로 사용되고 있으며, 또한 인체 내에 서 free radical에 의한 노화를 억제하는 작용의 척도로도 사용된다. 이러한 radical을 환원시키거나 상쇄하는 능력이 크면 높은 항산화 활성 및 활성산소를 비롯한 다른 radical에 대한 소거 작용을 기대할 수 있어(30), 본 연구의 재료인 
Table 2. Electron donating ability of extracts from Ligularia fischeri

\begin{tabular}{cccccc}
\hline \multirow{2}{*}{ Sample $^{1)}$} & \multicolumn{5}{c}{ Electron donating ability $(\%)$} \\
\cline { 2 - 6 } & $62.5 \mu \mathrm{g} / \mathrm{mL}$ & $125 \mu \mathrm{g} / \mathrm{mL}$ & $250 \mu \mathrm{g} / \mathrm{mL}$ & $500 \mu \mathrm{g} / \mathrm{mL}$ & $1,000 \mu \mathrm{gg} / \mathrm{mL}$ \\
\hline LWE & $68.77 \pm 0.64^{2 \mathrm{bb})}$ & $69.87 \pm 0.21^{\mathrm{c}}$ & $71.83 \pm 0.34^{\mathrm{b}}$ & $71.78 \pm 0.21^{\mathrm{c}}$ & $73.48 \pm 1.08^{\mathrm{c}}$ \\
LEE & $73.13 \pm 0.66^{\mathrm{a}}$ & $74.29 \pm 0.59^{\mathrm{a}}$ & $74.59 \pm 0.71^{\mathrm{a}}$ & $74.94 \pm 0.68^{\mathrm{b}}$ & $77.74 \pm 0.97^{\mathrm{b}}$ \\
AsA & $71.98 \pm 0.35^{\mathrm{a}}$ & $72.83 \pm 0.16^{\mathrm{b}}$ & $74.99 \pm 0.21^{\mathrm{a}}$ & $76.79 \pm 0.69^{\mathrm{a}}$ & $81.15 \pm 1.08^{\mathrm{a}}$ \\
\hline
\end{tabular}

${ }^{11}$ LWE, Ligularia fischeri water extract; LEE, Ligularia fischeri ethanol extract; AsA, ascorbic acid.

${ }^{2)}$ All value are expressed as Mean $\mathrm{SD}$ of triplicate determinations.

${ }^{3}$ Different superscripts within the column are significantly different at $p<0.05$ by Duncan's multiple range test.

곰취를 활용하여 다양한 천연 소재로서 이용될 수 있을 것으로 생각된다.

\section{SOD 유사활성}

곰취의 열수 및 $70 \%$ 에탄올 추출물의 superoxide dismutase(SOD) 유사활성 측정 결과는 Table 3과 같다. $\mathrm{SOD}$ 는 체내에 존재하는 항산화 효소로서 superoxide anion 을 과산화수소로 전환시켜 세포 내 super oxide anion 농도를 줄이는 중요한 역할을 담당한다. 곰취 열수 및 에탄올 추출 물의 농도가 증가함에 따라 SOD 유사활성능은 증가함을 보였다.

추출물 농도 $1,000 \mathrm{\mu g} / \mathrm{mL}$ 에서 곰취 열수 추출물인 $\mathrm{LWE}$ 는 $36.87 \%$, 곰취 에탄올 추출물 $\mathrm{LEE}$ 에서는 $44.80 \%$ 으로 열수 추출물보다 에탄올 추출물에서 SOD 유사활성능이
높았다. $62.5 \mu \mathrm{g} / \mathrm{mL}$ 농도에서는 대조구인 ascorbic acid가 $32.21 \%$ 의 SOD 유사활성능을 보였으며, 곰취 열수 추출물 $\mathrm{LWE}$ 에서 $29.03 \%$, 곰취 에탄올 추출물 $\mathrm{LEE}$ 에서 $34.23 \%$ 으 로 에탄올 추출물이 열수 추출물보다 SOD 유사활성능은 높았고 대조구에 비해서도 다소 높았다.

아질산염 소거능(nitrite scavenging ability)

곰취 열수 및 $70 \%$ 에탄올 추출물의 아질산염 소거능을 $\mathrm{pH} 1.2$ 와 $\mathrm{pH} 3.0$ 에서 측정한 결과는 Table 4와 같다.

$\mathrm{pH} 1.2$ 는 정상인의 위내 환경의 산도로 높은 값을 나타낼 수록 생체 내에서 아질산염을 소거하는 기능이 뛰어나다고 할 수 있는데 곰취 열수 및 에탄올 추출물의 아질산염 소거 능을 $\mathrm{pH} 1.2$ 에서 측정한 결과 열수 및 에탄올 추출물의 농도가 증가함에 따라 아질산염 소거능은 증가함을 보였

Table 3. SOD like activity of extracts from Ligularia fischeri

\begin{tabular}{cccccc}
\hline \multirow{2}{*}{ Sample $^{\mathrm{l})}$} & \multicolumn{5}{c}{ SOD like activity (\%) } \\
\cline { 2 - 6 } & $62.5 \mu \mathrm{g} / \mathrm{mL}$ & $125 \mu \mathrm{g} / \mathrm{mL}$ & $250 \mu \mathrm{g} / \mathrm{mL}$ & $500 \mu \mathrm{g} / \mathrm{mL}$ & $1,000 \mu \mathrm{g} / \mathrm{mL}$ \\
\hline LWE & $29.03 \pm 0.52^{2)(3)}$ & $29.53 \pm 0.42^{\mathrm{c}}$ & $32.84 \pm 2.23^{\mathrm{c}}$ & $33.92 \pm 1.12^{\mathrm{c}}$ & $36.87 \pm 3.04^{\mathrm{c}}$ \\
LEE & $34.23 \pm 0.37^{\mathrm{a}}$ & $37.32 \pm 1.34^{\mathrm{a}}$ & $41.67 \pm 0.96^{\mathrm{ab}}$ & $44.31 \pm 0.78^{\mathrm{b}}$ & $44.80 \pm 1.45^{\mathrm{b}}$ \\
AsA & $32.21 \pm 0.28^{\mathrm{b}}$ & $35.80 \pm 0.82^{\mathrm{ab}}$ & $43.19 \pm 1.32^{\mathrm{a}}$ & $50.00 \pm 0.32^{\mathrm{a}}$ & $62.05 \pm 1.93^{\mathrm{a}}$ \\
\hline
\end{tabular}

${ }^{1)}$ LWE, Ligularia fischeri water extract; LEE, Ligularia fischeri ethanol extract; AsA, ascorbic acid.

${ }^{2)}$ All value are expressed as Mean $\pm \mathrm{SD}$ of triplicate determinations.

${ }^{3}$ Different superscripts within the column are significantly different at $p<0.05$ by Duncan's multiple range test.

Table 4. Nitrite scavenging ability of extracts from Ligularia fischeri

\begin{tabular}{|c|c|c|c|c|c|c|}
\hline \multicolumn{2}{|c|}{ Sample ${ }^{1)}$} & \multicolumn{5}{|c|}{ Nitrite scavenging ability (\%) } \\
\hline & & $62.5 \mu \mathrm{g} / \mathrm{mL}$ & $125 \mu \mathrm{g} / \mathrm{mL}$ & $250 \mu \mathrm{g} / \mathrm{mL}$ & $500 \mu \mathrm{g} / \mathrm{mL}$ & $1,000 \mu \mathrm{g} / \mathrm{mL}$ \\
\hline \multirow{3}{*}{ pH 1.2} & LWE & $34.35 \pm 0.81^{2) b(3)}$ & $34.10 \pm 0.62^{\mathrm{c}}$ & $36.31 \pm 1.65^{\mathrm{c}}$ & $40.22 \pm 1.20^{c}$ & $45.02 \pm 0.90^{c}$ \\
\hline & LEE & $36.10 \pm 2.03^{b}$ & $37.04 \pm 1.38^{\mathrm{b}}$ & $42.99 \pm 1.57^{b}$ & $50.68 \pm 1.15^{\mathrm{b}}$ & $53.41 \pm 1.92^{\mathrm{b}}$ \\
\hline & AsA & $43.44 \pm 0.16^{\mathrm{a}}$ & $44.04 \pm 5.01^{\mathrm{a}}$ & $55.89 \pm 0.43^{\mathrm{a}}$ & $61.21 \pm 1.05^{\mathrm{a}}$ & $64.22 \pm 1.44^{\mathrm{a}}$ \\
\hline \multirow{3}{*}{ pH 3.0} & LWE & $28.44 \pm 1.26^{b}$ & $30.50 \pm 0.99^{\text {bc }}$ & $33.94 \pm 0.33^{b}$ & $35.81 \pm 0.99^{c}$ & $37.16 \pm 0.86^{\mathrm{c}}$ \\
\hline & LEE & $27.98 \pm 0.40^{\mathrm{bc}}$ & $29.05 \pm 1.26^{b}$ & $32.34 \pm 0.27^{\mathrm{c}}$ & $37.55 \pm 0.54^{b}$ & $45.31 \pm 0.82^{b}$ \\
\hline & AsA & $44.31 \pm 1.10^{\mathrm{a}}$ & $45.31 \pm 0.56^{\mathrm{a}}$ & $46.19 \pm 0.88^{\mathrm{a}}$ & $47.40 \pm 1.33^{\mathrm{a}}$ & $51.90 \pm 0.57^{\mathrm{a}}$ \\
\hline
\end{tabular}

${ }^{11}$ LWE, Ligularia fischeri water extract; LEE, Ligularia fischeri ethanol extract; AsA, ascorbic acid.

${ }^{2}$ All value are expressed as Mean \pm SD of triplicate determinations.

${ }^{3)}$ Different superscripts within the column are significantly different at $p<0.05$ by Duncan's multiple range test. 
다. 곰취 추출물 $1,000 \mu \mathrm{g} / \mathrm{mL}$ 의 농도에서 곰취 열수 추출물 인 LWE가 $45.02 \%$, 곰취 에탄올 추출물인 $\mathrm{LEE}$ 가 $53.41 \%$ 의 아질산염 소거능을 보여 에탄올 추출물에서 열수 추출물에 비해 높은 아질산염 소거능을 보였고, 대조구인 ascorbic acid에서 $64.22 \%$ 의 아질산염 소거능을 보였다. 곰취 추출물 의 농도 62.5-500 $\mathrm{\mu g} / \mathrm{mL}$ 에서는 곰취 열수 추출물인 LWE에 서 34.10\%-40.22\%의 아질산염 소거능을 보였으며, 곰취 에탄올 추출물인 LEE에서는 $37.04 \%-50.68 \%$ 의 아질산염 소거능을 보여 열수 추출물보다 에탄올 추출물에서 아질산 염 소거능이 높았다.

곰취 열수 및 에탄올 추출물의 아질산염 소거능을 $\mathrm{pH}$ 3.0 에서 측정한 결과 $\mathrm{pH} 1.2$ 에서 측정한 결과와 유사하게 열수 및 에탄올 추출물의 농도가 증가함에 따라 아질산염 소거능은 증가함을 보였다. 곰취 추출물 $1,000 \mu \mathrm{g} / \mathrm{mL}$ 의 농 도에서 대조구인 ascorbic acid에서 $51.90 \%$ 의 아질산염 소 거능을 보였고, 곰취 열수 추출물인 LWE가 $37.16 \%$, 곰취 에탄올 추출물인 LEE가 $45.31 \%$ 의 아질산염 소거능을 보여 에탄올 추출물에서 열수 추출물에 비해 아질산염 소거능이 높았다. 곰취 추출물의 농도 $62.5-500 \mathrm{\mu g} / \mathrm{mL}$ 에서는 곰취 열수 추출물인 LWE에서 $28.44 \%-35.81 \%$ 의 아질산염 소거 능을 보였으며, 곰취 에탄올 추출물인 LEE에서는 27.98$37.55 \%$ 의 아질산염 소거능을 보여 열수 추출물보다 에탄올 추출물에서 아질산염 소거능이 높은 경향이었다. 곰취의 열수 및 에탄올 추출물에 아질산염 소거능은 농도가 증가함 에 따라 아질산염 소거능은 증가함을 보였고, $\mathrm{pH} 1.2$ 에서 $\mathrm{pH}$ 3.0보다 아질산염 소거능이 높았다. 이러한 결과는 아질 산염 소거능이 $\mathrm{pH}$ 에 매우 의존적이며 $\mathrm{pH}$ 가 높을수록 소거 효과가 감소된다는 Kytopoulos(31)의 결과와도 일치하였 다. 아질산염을 많이 포함한 식품을 다량 섭취시 nitro화 반응이 강산성인 위장에서 쉽게 일어나 발암물질을 생성하 게 된다(32). 이 반응을 참고하여 본 연구의 재료인 곰취를 이용한 다양한 식품연구 개발 시 치료식품이나 약품, 항산 화성이 부여된 기능성 식품 등으로 이용될 수 있을 것이다.

ABTS(ABTS radical scavenging)라디칼 소거활성 측정

곰취의 열수 및 에탄올 추출물로 $\mathrm{ABTS}$ 라디칼 소거활성
측정한 결과는 Table 5 와 같다. 곰취 열수 및 에탄올 추출물 의 항산화 활성의 정도를 측정하고자 농도별로 $\mathrm{ABTS}$ 라디 칼 소거활성능을 측정하였다. $1,000 \mu \mathrm{gg} / \mathrm{mL}$ 의 농도에서 곰 취 열수 추출물인 LWE가 $74.21 \%$, 곰취 에탄올 추출물인 $\mathrm{LEE}$ 에서 $95.96 \%$ 의 $\mathrm{ABTS}$ 라디칼 소거활성을 보였으며, 대조구인 butyl hydroxy toluene은 $98.34 \%$ 으로 곰취 에탄올 추출물의 경우 대조구만큼 $\mathrm{ABTS}$ 라디칼 소거활성이 높았 다. $62.5 \mu \mathrm{g} / \mathrm{mL}$ 의 농도에서는 곰취 열수 추출물인 LWE가 $1.66 \%$, 곰취 에탄올 추출물인 $\mathrm{LEE}$ 에서 $2.20 \%$ 의 $\mathrm{ABTS}$ 라 디칼 소거활성을 보였으며, 대조구인 butyl hydroxy toluene 은 $1.47 \%$ 으로 곰취 에탄올 추출물의 경우 대조구보다도 $\mathrm{ABTS}$ 라디칼 소거활성이 높았다. 전반적으로 곰취 열수 및 에탄올 추출물의 농도가 증가함에 따라 ABTS 라디칼 소거활성은 증가함을 보였다.

다양한 기능성 물질이 포함되어 있으며 약용, 식용으로 이용되는 오미자, 산수유, 구기자, 복분자 열수 추출물의 ABTS 라디칼 소거활성이 $250-1,000 \mu \mathrm{g} / \mathrm{mL}$ 농도에서 33.43$90.49 \%$ 의 보고(33)와 비교해보면 본 연구 결과에서는 곰취 열수 및 에탄올 추출물 $1,000 \mu \mathrm{g} / \mathrm{mL}$ 농도에서 $74.21,95.96 \%$ 의 $\mathrm{ABTS}$ 라디칼 소거활성을 보인 결과와 비교해보면 곰취 의 열수 및 에탄올 추출물에서도 항산화성 물질을 함유하고 있을 것으로 생각된다.

\section{Xanthine oxidase 저해효과}

곰취의 열수 및 $70 \%$ 에탄올 추출물의 xanthine oxidase 저해효과를 측정한 결과는 Table 6과 같다. 곰취 열수 및 에탄올 추출물의 농도가 증가함에 따라 xanthine oxidase 저해효과는 증가함을 보였다. 곰취 추출물 $1,000 \mu \mathrm{g} / \mathrm{mL}$ 의 농도에서 곰취 열수 추출물인 $\mathrm{LWE}$ 에서 $61.00 \%$, 곰취 에탄 올 추출물인 LEE에서 $82.35 \%$, 대조구인 ascorbic acid는 $88.67 \%$ 의 xanthine oxidase 저해효과를 보여 열수 추출물보 다 에탄올 추출물에서 xanthine oxidase 저해효과가 높았다. $125-500 \mathrm{\mu g} / \mathrm{mL}$ 의 농도에서는 곰취 열수 추출물인 LWE에 서 43.57-50.76\%의 xanthine oxidase 저해효과를 보였고, 곰 취 에탄올 추출물인 LEE에서는 $40.74-50.33 \%$ 의 xanthine oxidase 저해효과를 보여 곰취 열수 및 에탄올 추출물의 xanthine oxidase 저해효과는 유의적인 차이가 없었다. 62.5

Table 5. ABTS radical scavenging activity of extracts from Ligularia fischeri

\begin{tabular}{cccccc}
\hline \multirow{2}{*}{ Sample $^{1)}$} & \multicolumn{5}{c}{ ABTS radical scavenging activity } \\
\cline { 2 - 6 } & $62.5 \mu \mathrm{g} / \mathrm{mL}$ & $125 \mu \mathrm{g} / \mathrm{mL}$ & $250 \mu \mathrm{g} / \mathrm{mL}$ & $500 \mu \mathrm{g} / \mathrm{mL}$ & $1,000 \mu \mathrm{g} / \mathrm{mL}$ \\
\hline LWE & $1.66 \pm 0.30^{2 \mathrm{ab} 3)}$ & $2.08 \pm 0.61^{\mathrm{c}}$ & $3.92 \pm 0.60^{\mathrm{c}}$ & $16.46 \pm 0.30^{\mathrm{c}}$ & $74.21 \pm 0.20^{\mathrm{b}}$ \\
LEE & $2.20 \pm 0.52^{\mathrm{a}}$ & $3.92 \pm 0.83^{\mathrm{b}}$ & $12.66 \pm 0.40^{\mathrm{b}}$ & $62.69 \pm 0.80^{\mathrm{b}}$ & $95.96 \pm 0.24^{\mathrm{a}}$ \\
BHT & $1.47 \pm 0.20^{\mathrm{ab}}$ & $6.71 \pm 0.30^{\mathrm{a}}$ & $63.10 \pm 0.05^{\mathrm{a}}$ & $94.71 \pm 0.90^{\mathrm{a}}$ & $98.34 \pm 0.10^{\mathrm{a}}$ \\
\hline
\end{tabular}

\footnotetext{
${ }^{1)}$ LWE, Ligularia fischeri water extract; LEE, Ligularia fischeri ethanol extract; BHT, butyl hydroxy toluene.

${ }^{2}$ All value are expressed as Mean $\pm \mathrm{SD}$ of triplicate determinations.

${ }^{3)}$ Different superscripts within the column are significantly different at $p<0.05$ by Duncan's multiple range test.
} 
Table 6. Inhibitory effect on the xanthine oxidase of extracts from Ligularia fischeri

\begin{tabular}{cccccc}
\hline \multirow{2}{*}{ Sample $^{1)}$} & \multicolumn{5}{c}{ Xanthine oxidase inhibition (\%) } \\
\cline { 2 - 6 } & $62.5 \mu \mathrm{g} / \mathrm{mL}$ & $125 \mu \mathrm{gg} / \mathrm{mL}$ & $250 \mu \mathrm{g} / \mathrm{mL}$ & $500 \mu \mathrm{g} / \mathrm{mL}$ & $1,000 \mu \mathrm{g} / \mathrm{mL}$ \\
\hline LWE & $\left.\left.34.64 \pm 7.00^{2}\right) \mathrm{bcc}\right)$ & $43.57 \pm 10.20^{\mathrm{b}}$ & $44.44 \pm 1.94^{\mathrm{b}}$ & $50.76 \pm 0.75^{\mathrm{b}}$ & $61.00 \pm 9.21^{\mathrm{b}}$ \\
LEE & $36.82 \pm 9.49^{\mathrm{b}}$ & $40.74 \pm 6.36^{\mathrm{b}}$ & $44.44 \pm 3.83^{\mathrm{b}}$ & $50.33 \pm 4.90^{\mathrm{b}}$ & $82.35 \pm 3.39^{\mathrm{a}}$ \\
AsA & $59.04 \pm 8.28^{\mathrm{a}}$ & $61.22 \pm 3.42^{\mathrm{a}}$ & $65.58 \pm 4.06^{\mathrm{a}}$ & $80.17 \pm 3.29^{\mathrm{a}}$ & $88.67 \pm 5.47^{\mathrm{a}}$ \\
\hline
\end{tabular}

${ }^{1)}$ LWE, Ligularia fischeri water extract; LEE, Ligularia fischeri ethanol extract; AsA, ascorbic acid.

${ }^{2)}$ All value are expressed as Mean $\mathrm{SD}$ of triplicate determinations.

${ }^{3}$ Different superscripts within the column are significantly different at $p<0.05$ by Duncan's multiple range test.

$\mu \mathrm{g} / \mathrm{mL}$ 의 농도에서는 곰취 열수 추출물인 LWE에서 $34.64 \%$ 의 xanthine oxidase 저해효과를 보였고, 곰취 에탄올 추출 물인 LEE에서는 $36.82 \%$ 으로 곰취 열수 추출물에서 xanthine oxidase 저해효과가 다소 높았다.

Xanthine oxidase는 분자상의 산소를 수소 수용체로 이용 하여 촉매작용으로 xanthine을 uric acid형으로 산화하는 반응을 하기 때문에 xanthine oxidase 저해효과는 유리라디 칼의 생성 억제와 함께 혈청 내에서 urea가 증가 될 시에는 통풍을 일으키므로 생물학적으로 중요한 의의를 가진다고 할 수 있다(34). 따라서 본 연구의 곰취 열수 및 에탄올 추출물에서도 xanthine oxidase 저해효과가 있어 통풍의 예 방과 생약 치료제의 개발 및 이용이 가능할 것으로 생각된 다.

\section{Tyrosinase 저해 활성}

곰취의 열수 및 $70 \%$ 에탄올 추출물의 tyrosinase 저해 활성을 측정한 결과는 Table 7과 같다. $1,000 \mathrm{\mu g} / \mathrm{mL}$ 의 농도 에서는 대조구인 ascorbic acid에서 $80.37 \%$ 의 tyrosinase 저 해 활성을 보였고, 곰취 열수 추출물인 LWE에서는 $61.46 \%$, 곰취 에탄올 추출물인 LEE에서는 $67.72 \%$ 의 tyrosinase 저 해 활성을 보여 곰취 에탄올 추출물 $\mathrm{LEE}$ 에서 곰취 열수 추출물인 LWE에 비해 tyrosinase 저해 활성이 높았다.

곰취 열수 및 에탄올 추출물 $62.5-500 \mathrm{\mu g} / \mathrm{mL}$ 농도의 tyrosinase 저해 활성에서는 곰취 열수 추출물인 LWE에서 $35.90-50.46 \%$ 의 tyrosinase 저해 활성을 보였으며, 곰취 에 탄올 추출물인 LEE에서는 $38.27-53.75 \%$ 의 tyrosinase 저해 활성을 보여 곰취 열수 추출물인 LWE보다 곰취 에탄올
추출물인 LEE에서 tyrosinase 저해 활성이 다소 높았다. 그 리고 곰취 열수 및 에탄올 추출물의 농도가 증가할수록 tyrosinase 저해 활성이 높았다.

페놀류의 함량이 높을수록 tyrosinase 저해 효과가 높다 는 연구보고가 있고 식물의 여러 페놀 화합물이 tyrosinase 저해능이 있다고 밝혀진 바가 있으나(35) 모든 페놀 화합물 이 tyrosinase 저해능이 있는 것은 아니다(36). 하지만 본 연구결과와 같이 곰취 열수 및 에탄올 추출물에서도 일정량 의 페놀이 함유되어 있어 tyrosinase 저해 활성 효과에서도 우수한 결과를 보인 것으로 생각된다.

환원력

곰취의 열수 및 $70 \%$ 에탄올 추출물의 항산화 활성 정도 를 측정하고자 농도별 환원력을 측정하였으며 측정 결과는 Table 8과 같으며, 대조구는 BHT를 사용하였다. 곰취 열수 및 에탄올 추출물의 농도가 증가할수록 환원력은 증가함을 보였다. 곰취 추출물 $1,000 \mu \mathrm{g} / \mathrm{mL}$ 의 농도에서 곰취 열수 추출물인 LWE와 곰취 에탄올 추출물인 LEE에서 1.20 로 환원력이 같았다. 곰취 추출물 $62.5-500 \mu \mathrm{gg} / \mathrm{mL}$ 의 농도에서 곰취 열수 추출물인 LWE는 0.29-1.13의 환원력을 보였고, 곰취 에탄올 추출물인 LEE에서는 $0.20-1.01$ 의 환원력을 보 여 곰취 열수 추출물인 $\mathrm{LWE}$ 가 곰취 에탄올 추출물인 $\mathrm{LEE}$ 보다 환원력이 높았다.

Osawa(37)은 phenolic compound는 가용성 식물류에 널 리 분포되어 있는 것으로 항산화능을 포함하여 다양한 생물 학적 효능을 나타낸다고 보고하였는데 이는 식물의 한 종류 인 곰취 열수 및 에탄올 추출물에서 우수한 환원력을 보여

Table 7. Inhibitory effect on the tyrosinase of extracts from Ligularia fischeri

\begin{tabular}{cccccc}
\hline \multirow{2}{*}{ Sample $^{1)}$} & \multicolumn{5}{c}{ Tyrosinase inhibition (\%) } \\
\cline { 2 - 6 } & $62.5 \mu \mathrm{g} / \mathrm{mL}$ & $125 \mu \mathrm{g} / \mathrm{mL}$ & $250 \mu \mathrm{g} / \mathrm{mL}$ & $500 \mu \mathrm{g} / \mathrm{mL}$ & $1,000 \mu \mathrm{g} / \mathrm{mL}$ \\
\hline LWE & $35.90 \pm 0.71^{2 \mathrm{bb} 3)}$ & $39.06 \pm 0.80^{\mathrm{c}}$ & $46.25 \pm 0.31^{\mathrm{c}}$ & $50.46 \pm 2.41^{\mathrm{bc}}$ & $61.46 \pm 6.13^{\mathrm{c}}$ \\
LEE & $38.27 \pm 1.47^{\mathrm{ab}}$ & $44.20 \pm 2.68^{\mathrm{b}}$ & $52.96 \pm 0.35^{\mathrm{b}}$ & $53.75 \pm 6.08^{\mathrm{b}}$ & $67.72 \pm 0.37^{\mathrm{b}}$ \\
AsA & $41.11 \pm 0.47^{\mathrm{a}}$ & $50.72 \pm 0.44^{\mathrm{a}}$ & $60.14 \pm 1.12^{\mathrm{a}}$ & $74.70 \pm 1.69^{\mathrm{a}}$ & $80.37 \pm 0.10^{\mathrm{a}}$ \\
\hline
\end{tabular}

${ }^{11}$ LWE, Ligularia fischeri water extract; LEE, Ligularia fischeri ethanol extract; AsA, ascorbic acid.

${ }^{2)}$ All value are expressed as Mean \pm SD of triplicate determinations.

${ }^{3}$ Different superscripts within the column are significantly different at $p<0.05$ by Duncan's multiple range test. 
Table 8. Reducing power of extracts from Ligularia fischeri

(Absorbance $700 \mathrm{~nm}$ )

\begin{tabular}{cccccc}
\hline \multirow{2}{*}{ Sample $^{1)}$} & \multicolumn{5}{c}{ Reducing power } \\
\cline { 2 - 6 } & $62.5 \mu \mathrm{g} / \mathrm{mL}$ & $125 \mu \mathrm{g} / \mathrm{mL}$ & $250 \mu \mathrm{g} / \mathrm{mL}$ & $500 \mu \mathrm{g} / \mathrm{mL}$ & $1,000 \mu \mathrm{g} / \mathrm{mL}$ \\
\hline LWE & $0.29 \pm 0.01^{2) \mathrm{b} 3)}$ & $0.38 \pm 0.01^{\mathrm{b}}$ & $0.56 \pm 0.05^{\mathrm{b}}$ & $1.13 \pm 0.01^{\mathrm{b}}$ & $1.20 \pm 0.01^{\mathrm{b}}$ \\
LEE & $0.20 \pm 0.01^{\mathrm{c}}$ & $0.23 \pm 0.01^{\mathrm{c}}$ & $0.41 \pm 0.02^{\mathrm{c}}$ & $1.01 \pm 0.01^{\mathrm{c}}$ & $1.20 \pm 0.04^{\mathrm{b}}$ \\
BHT & $0.38 \pm 0.01^{\mathrm{a}}$ & $0.62 \pm 0.01^{\mathrm{a}}$ & $0.95 \pm 0.04^{\mathrm{a}}$ & $1.80 \pm 0.20^{\mathrm{a}}$ & $1.83 \pm 0.01^{\mathrm{a}}$ \\
\hline
\end{tabular}

${ }^{1}$ LWE, Ligularia fischeri water extract; LEE, Ligularia fischeri ethanol extract; BHT, butyl hydroxy toluene

${ }^{2}$ All value are expressed as Mean $\mathrm{SD}$ of triplicate determinations.

${ }^{3}$ Different superscripts within the column are significantly different at $p<0.05$ by Duncan's multiple range test.

다양한 식품개발에 활용 가능할 것으로 생각된다.

\section{References}

\section{요 약}

본 연구는 기능성 소재 개발 가능성을 위해 곰취의 열수 및 $70 \%$ 에탄올 추출방법에 따른 추출물의 항산화 및 생리 활성에 대하여 연구하였다. 수율 측정 결과 곰취 열수 추출 물은 $15.23 \%$, 곰취 에탄올 추출물은 $17.45 \%$ 로 에탄올 추출 물의 수율이 높았다. 총 폴리페놀 및 플라보노이드 함량 결과 곰취 에탄올 추출물인 LEE에서 각각 $17.17 \pm 4.38 \mathrm{mg} / \mathrm{g}$, $35.06 \pm 6.69 \mathrm{mg} / \mathrm{g}$ 으로 함량이 높았다. 곰취 추출물의 전자공 여능과 $\mathrm{SOD}$ 유사활성능, $\mathrm{ABTS}$ 라디칼 소거활성은 농도가 증가함에 따라 증가함을 보였으며, 곰취 에탄올 추출물인 $\mathrm{LEE}$ 에서 전체적으로 높은 활성을 보였다. 아질산염 소거능 은 곰취 추출물의 농도가 증가함에 따라 아질산염 소거능은 증가함을 보였고, $\mathrm{pH} 1.2$ 가 $\mathrm{pH}$ 3.0보다 아질산염 소거능이 높았다. Xanthine oxidase 저해 효과와 tyrosinase 저해 활성 은 곰취 열수 및 에탄올 추출물의 모든 농도에서 농도 의존 적으로 증가하는 경향을 보였으며 특히 곰취 에탄올 추출물 인 LEE에서 저해효과가 높았다. 환원력은 곰취 추출물 $1,000 \mathrm{\mu g} / \mathrm{mL}$ 의 농도에서 곰취 열수 추출물인 LWE와 곰취 에탄올 추출물인 LEE에서 1.20 로 환원력이 유사하였고, 곰취 추출물 62.5-500 $\mathrm{\mu g} / \mathrm{mL}$ 의 농도에서는 곰취 열수 추출 물인 LWE의 환원력이 높았다. 따라서 곰취의 열수 및 에탄 올 추출물의 항산화 및 생리활성에 대한 연구 결과 곰취가 항산화 및 생리활성이 우수하여 천연 항산화 소재로서의 활용 가능한 약용식물 자원이며, 이를 활용한 가공 산업 및 지역 특산물 발전의 기초자료가 될 것으로 생각된다.

\section{감사의 글}

본 연구는 2016년도 대구한의대학교 기린연구비 (2016-901-11) 지원에 의해 수행되었으며, 이에 감사드립니 다.
1. Kim KA, Jung LH, Jeon ER, Jeong JA (2005) Consciousness on the Korean traditional food of school food service dietitians. Korean J Home Econ Assoc, 43, 127-142

2. Mun SH, Surh JH (2017) Effect of corn oil as an oil phase on the preparation and characterization of oil-in-water nanoemulsions fabricated by spontaneous emulsification. Korean J Food Cook Sci, 33, 427-434

3. Lee KA (2017) Antioxidative and antidiabetic effects of roasted Gugija(Lycii fructus) extracts. Korean J Food Cook Sci, 33, 413-419

4. Kang JR, Kang MJ, Shin JH, Park JH, Kim DI, Chung SY, Shin JH (2017) Antioxidant and antidiabetic activities of various solvent extracts from Stachys sieboldii Miq. Korean J Food Preserv, 24, 615-622

5. Kang KJ, Chung MS (1995) A Study on housewives consumption pattern and nutrition knowledge about vegetables. Korean J Dietary Culture, 10, 377-390

6. Ham SS, Lee SY, Oh DH, Kim SH, Hong JK (1997) Development of beverages drinks using mountain edible herbs. J Korean Soc Food Sci Nutr, 26, 92-97

7. Cho EJ (2000) A survey on the usage of wild grasses. Korean J Dietary Culture, 15, 59-68

8. Ham YA, Choi HJ, Chung MJ, Ham SS (2009) Component analysis and antioxidant activity of Adenophora triphylla. J Korean Soc Food Sci Nutri, 38, 274-279

9. Whang TE, Lim HO, Lee JW (1999) Effects of fermented (Oenanthe stolonifera DC) extract on the activity of enzymes related to liver function of alcohol-administered rats and mice. Korean J Med Crop Sci, 7, 107-114

10. Choi HJ, Chung MJ, Ham SS (2010) Antiobese and hypo cholesterol aemic effects of an Adenophora triphylla extract in HepG2 cells and high fat diet-induced obese 
mice and high fat diet-induced obese mice. Food Chem, $119,437-444$

11. Moon YG, Choi KS, Lee KJ, Kim KY, Heo MS (2006) Screening of antioxidant and antibacterial activity from hot water of indigenous plants, Jeju-Island. Korean J Biotechnol Bioeng, 21, 164-169

12. Oh DH (2011) Industry plan of wild edible greens. Food Preservation and Processing Industry, 10, 9-17

13. Park BH, Kim M, Jeon ER (2013) Quality characteristics of tofu added Ligularia fischeri powder. Korean J Food Culture, 28, 495-501

14. Chang SK, Kim JH, Oh HS (2008) The development of functional cold buckwheat noodles using biological activities of hot water extracts of Ligularia fischeri and Angelica gigas Nakai. Korean J Food Culture, 23, 479-488

15. Kim SM, Kang SW, Um BH (2010) Extraction conditions of radical scavenging caffeoylquinic acids from Gomchui(Ligularia fischeri) tea. J Korean Soc Food Sci Nutr, 39, 399-405

16. Cho SD, Kim GH (2005) Food product development and quality characteristics of Ligularia fischeri for food resources. Korean J Food Preserv, 12, 43-47

17. Ahn SM, Kim MS, Jung IC, Sohn HY (2011) Antibacterial, antioxidative and anti-proliferative activity against human colorectal cell of Pimpinella brachycarpa. Korean J Food Preserv, 18, 590-596

18. Singleton VL, Rossi JA (1965) Colorimetry of total phenolics with phosphomolybdic-phosphotungstic acid reagents. Am J Enol Viticult, 16, 144-158

19. Moreno MIN, Isla MI, Sampietro AR, Vattuone MA (2000) Comparison of the free radical-scavenging activity of propolis from several regions of Argentina. J Ethnopharmacol, 71, 109-114

20. Blois ML (1958) Antioxidant determination by the use of a stable free radical. Nature, 181, 1199-1200

21. Marklund S, Marklund G (1974) Involvement of the superoxide anion radical in the autioxidation of pyrogallol and a convenient assay for superoxide dismutase. Eur J Biochem, 47, 469-474

22. Re R, Pellegrini N, Proteggente A, Pannala A, Yang M, Rice-Evans C (1999) Antioxidant activity applying an improved ABTS radical cation decolorization assay. Free Radical Biol Med, 26, 1231-1237

23. Kato H, Lee IE, Chuyen NV, Kim SB, Hayase F (1987) Inhibition of nitrosamine formation by nondialyzable melanoidins. Agric Biol Chem, 51, 1333-1338
24. Stirpe F, Corte ED (1969) The regulation of rat liver xanthine oxidase. J Biol Chem, 244, 3855-3863

25. Yagi A, Kanbara T, Morinobu N (1987) Inhibition of mushroom-Tyrosinase by aloe extract. Planta Medica, 53, 515-517

26. Wong JY, Chye FY (2009) Antioxidant properties of selected tropical wild edible mushrooms. J Food Compos Anal, 22, 269-277

27. Park WP (2014) Quality characteristics of noodles added with Houttuynia cordata Thunb. powder. Korean J Food Preserv, 21, 34-39

28. Hong JY, Kim KM, Nam HS, Shin SR (2014) Antioxidant activities of hot-water extracts from Aster scaber by cultivation and drying methods. Korean J Food Preserv, $21,82-90$

29. Moon JS, Kim SJ, Park YM, Hwang IS, Kim EH, Park JW, Park IB, Kim SW, Kang SG, Park YK, Jung ST (2004) Activities of antioxidation and alcohol dehydrogenase inhibition of methanol extracts from some medicinal herbs. Korean J Food Preserv, 11, 201-206

30. Isono R, Yo shimura T, Esumi K (2005) Preparation of $\mathrm{Au} / \mathrm{TiO} 2$ nano composities and their catalytic activity for DPPH radical scavenging reaction. J Colloid Interface Sci, 288, 177-183

31. Kytopoulos SA (1987) Ascorbic acid and the formation of $\mathrm{N}$-nitroso compounds: possible role of ascorbic acid in cancer prevention. Am J Clin Nutr, 45, 1344-1350

32. Messey RC, Crews C, Davies R, McWeeney DJ (1978) A study of the competitive nitrosations of pyrrolidine, ascorbic acid, cysteine and p-cresol in a protein-based model system. J Sci Food Agric, 29, 815-821

33. Gu YR, Park HM, Jeong YS, Jung HK, Yun JH, Hong JH (2016) Physicochemical properties and antioxidant activities of hot water extracts from medicinal fruit mixture. Korean J Food Presev, 23, 267-274

34. Draper HH, Bird RP (1984) Antioxidant and cancer. J Agric Food Chem, 32, 433-435

35. Boissy RE, Manga P (2004) On the etiology of contact occupational vitiligo. Pigment Cell Res, 17, 208-214

36. Chan EWC, Lim YY, Wong LF, Lianto FS, Wong SK, Lim KK, Joe CE, Lim TY (2008) Antioxidant and tyrosinase inhibition properties of leaves and rhizomes of ginger species. Food Chem, 109, 477-483

37. Osawa T (1994) Novel netural antioxidants for utilization in food and biological system. Postharvest biochemistry of plant food materials in the tropics. Japan Scientific Societies Press, Tokyo, Japan, 241-251 